\title{
Effect of Heat Treatment of Cu-Al-Be Shape Memory Alloy on Microstructure, Shape Memory Effect and Hardness
}

Jafar Tahar. Al-Haidary, Ali Mundher Mustafa and Ahmed Aziz Hamza*
Department of Production Engineering and Metallurgy, University of Technology, Iraq

\begin{abstract}
$\mathrm{Cu}-13 \mathrm{Al}-0.545 \mathrm{Be}$ shape memory alloy are heat treatment at different temperature and time. The microstructure of alloy after heat treatment at $850^{\circ} \mathrm{C}, 650^{\circ} \mathrm{C}$ and aging at $150^{\circ} \mathrm{C}, 450^{\circ} \mathrm{C}$ and $550^{\circ} \mathrm{C}$ for 2,4 and $6 \mathrm{~h}$ study by optical microscope and X-ray diffraction. Bending test is use to show effect of heat treatment on super-elastic and shape memory effect.

Micro hardness test used to show effect of heat treatment on micro hardness .shape memory effect increase at heat treatment $650^{\circ} \mathrm{C}$ and aging at $150^{\circ} \mathrm{C}$, while at $450^{\circ} \mathrm{C}$ and $550^{\circ} \mathrm{C}$ will decrease because precipitate formation rate rises with increase in temperature and time. The hardness and precipitates in the alloy increases with increasing ageing duration. Higher ageing temperature avoids the imperfection by moving and filling the empty space thereby hardens the alloy.
\end{abstract}

Keywords: Alloys; Materials; Thermomechanical; Stabilization

\section{Introduction}

Previous investigations on $\mathrm{Cu}-(11.4-11.8$ wt.\%)Al shape memory Alloys with the addition of small quantities of beryllium have shown that they exhibit the pseudo-elastic effect at room temperature, due to the martensitic transformation from the $\mathrm{b}$ phase to $18 \mathrm{R}$ martensite. Shape memory alloys are the metallic group of materials and these materials are used in many application fields as it is capable of recovering its initial shape when exposed to variation of temperature or stress. Understanding of their microstructure and thermal behaviors has brought a major impact on their applications, as in case of aerospace, automotive and robotics components are needed to achieve further improvement in the properties as it require higher transformation temperatures, The thermomechanical properties of $\mathrm{Cu}-\mathrm{Al}-\mathrm{Be}$ alloys have been studied, and their use is highly promising for applications as passive dampers of seismic energy in buildings and in bridges, When these alloys are submitted to heat treatments like a slow cooling from high temperature or an isothermal heating, the formation of precipitates can be produced, and their presence can affect their shape memory properties. Aged $\mathrm{Cu}-\mathrm{Al}-\mathrm{Mn}$ SMAs results in transformation of $\beta^{\prime} 1$ martensite to $\gamma^{\prime} 1$ martensitic which leads to change in the shape memory characteristics and transformation temperatures. $\mathrm{Cu}-\mathrm{Al}-\mathrm{Mn}$ Alloys aged above $500^{\circ} \mathrm{C}$ does not show martensitic transformation, because of formation of large quantities of precipitates. $\mathrm{Cu}-\mathrm{Al}-\mathrm{Be}$ alloys show good strain recovery and shape memory effects. Microstructure of as-cast specimens shows austenitic microstructure and after quenching same specimens shows completely lath martensitic microstructure [1-4].

\section{Experimental Work}

The alloy $\mathrm{Cu}-13 \mathrm{Al} \%-0.545 \mathrm{Be} \%$ was imported from France, Chemical composition analysis of $\mathrm{Cu}-\mathrm{Al}-\mathrm{Be}$ alloy was carried by oxford foundry expert type in central organization for standardization and quality control-Baghdad (Figure 1). Table 1 show chemical composition of $\mathrm{Cu}-\mathrm{Al}-\mathrm{Be}$ alloy.

Homogenization at $800^{\circ} \mathrm{C}$ for 3 hour in electric box furnace and betatization and quenching from $800^{\circ} \mathrm{C}$ in salt ice water. Heat treatment at $650^{\circ} \mathrm{C}$ and aging at $150^{\circ} \mathrm{C}, 450^{\circ} \mathrm{C}$ and $550^{\circ} \mathrm{C}$ in electric box France for 2, 4 and 6 hour and quenching in ice water with salt Figure 2 shows electric box furnace.
For microstructure the samples are grinding using different wet paper 120,320,500,1000, 2000 and wishing with water ,polishing with cloth diamond and lubricant using polishing device then samples wishing with water, etching with solution $5 \mathrm{~g} \mathrm{FeCl}_{3}, 10 \mathrm{ml} \mathrm{HCL}$ and $100 \mathrm{ml} \mathrm{H}_{2} \mathrm{O}$. Theses process is done in samples preparation at metal
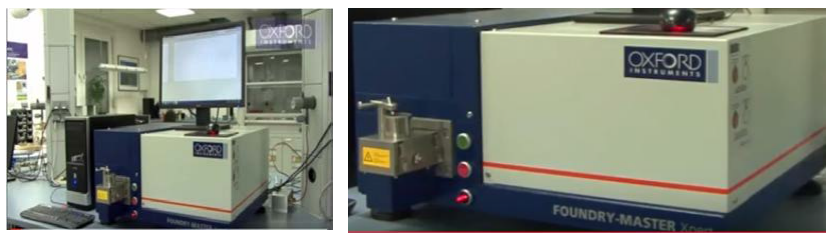

Figure 1: Oxford foundry master expert type chemical composition.

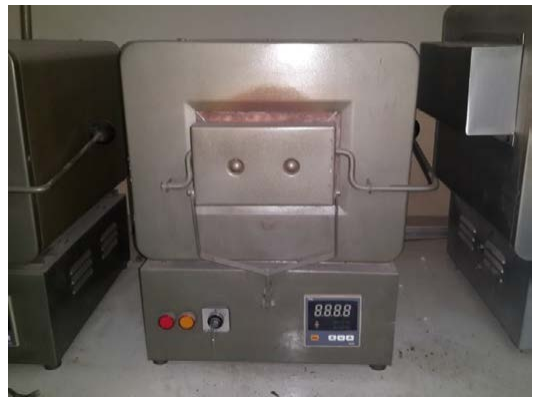

Figure 2: Electric resistance box furnace type for aging samples.

*Corresponding author: Ahmed Aziz Hamza, Department of Production Engineering and Metallurgy, Universty of Technology, Iraq, Tel: +964 790144 9044; E-mail: ah_azez1583@yahoo.com

Received November 03, 2017; Accepted November 22, 2017; Published December 02, 2017

Citation: Al-haidary JT, Mastafa AM, Aziz Hamza A (2017) Effect of Heat Treatment of Cu-Al-Be Shape Memory Alloy on Microstructure, Shape Memory Effect and Hardness. J Material Sci Eng 6: 398. doi: 10.4172/2169-0022.1000398

Copyright: (c) 2017 Al-haidary JT, et al. This is an open-access article distributed under the terms of the Creative Commons Attribution License, which permits unrestricted use, distribution, and reproduction in any medium, provided the original author and source are credited. 
Citation: Al-haidary JT, Mastafa AM, Aziz Hamza A (2017) Effect of Heat Treatment of Cu-Al-Be Shape Memory Alloy on Microstructure, Shape Memory Effect and Hardness. J Material Sci Eng 6: 398. doi: 10.4172/2169-0022.1000398

Page 2 of 7

laboratory - production engineering and metallurgy - University of technology-Baghdad (Figure 3).

Types of phases in the alloys were determined by optical microscope and using X-ray diffraction device type (shimadzu XRD-6000 X-Ray diffractmeter) (Figure 4).

For Shape memory effect Bending test is use to show effect of heat treatment on superelastic and shape memory effect. Wire specimen of alloy with dimensions $1.2 \mathrm{~mm}$ diameter and $50 \mathrm{~mm}$ length is used in this bending test (Figure 5).
$\mathrm{SME}=\theta \mathrm{m} / 180$

Where,

$\theta \mathrm{e}=$ angle recovered on unloading.

$\theta \mathrm{m}=$ angle recovered on heating.

Microhardness test used to show effect of heat treatment on microhardness. Heat treatment at different temperature, time and quenching media led to effect on microstructure and phases therefore effect on microhardness (Figure 6).

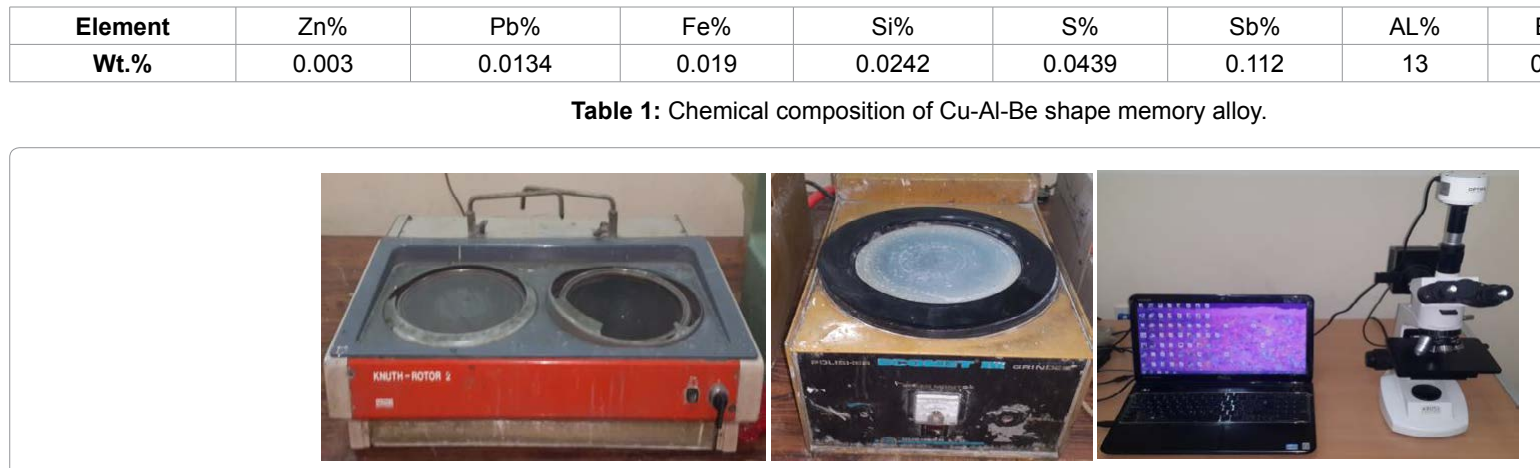

Figure 3: (a) Electric disk rotary grinding, (b) polishing device (c) optical microscope for microstructure observation.

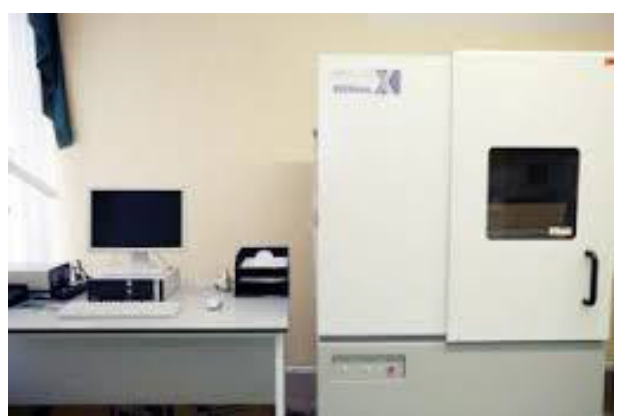

Figure 4: XRD 6000 shimadzu type.

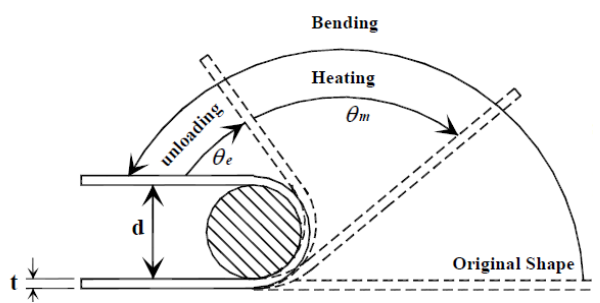

Figure 5: Schematic diagram of bending test for measuring shape memory effect.

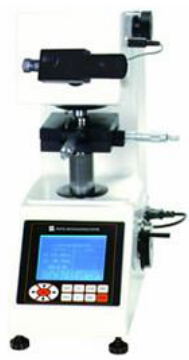

Figure 6: Micro Vickers hardness device models TH714 type. 
Citation: Al-haidary JT, Mastafa AM, Aziz Hamza A (2017) Effect of Heat Treatment of Cu-Al-Be Shape Memory Alloy on Microstructure, Shape Memory Effect and Hardness. J Material Sci Eng 6: 398. doi: 10.4172/2169-0022.1000398

Page 3 of 7

$\mathrm{HV}=1.845 \mathrm{P} / \mathrm{d}^{2}$

$\mathrm{P}=$ applied load, $\mathrm{d}=$ length of diagonal.

\section{Result and Discussion}

\section{Microstructure}

Heat treatment at $850^{\circ} \mathrm{C}$ at $3 \mathrm{~h}$ and quenching in ice water with salt have plate of martensite phase. While microstructure of sample at $650^{\circ} \mathrm{C}$ at 2 hour was martensite and $\gamma_{2}$ phase, at 4 and $6 \mathrm{~h}$ was martensite phase. The martensite transformation is not appreciably effected by $100 \mathrm{~h}$ at $220^{\circ} \mathrm{C}$ or $260^{\circ} \mathrm{C}$. Beyond annealing for $200 \mathrm{~h}$ at theses temperature, martensite transformation degradation is noticed caused by the precipitation phenomenon. Aging of martensite phase at $450^{\circ} \mathrm{C}$ will precpitate $\left(\alpha+\gamma_{2}\right)$ phase according to phase diagram of $\mathrm{Cu}$ $\mathrm{Al}-\mathrm{Be}$, Increasing aging time led to increase amount of precipitate of $\gamma^{2}$ have $\mathrm{Cu}_{9} \mathrm{Al}_{4}$ (high Aluminum content) and $\alpha$ (low aluminium content). aging at $550^{\circ} \mathrm{C}$ will precipitate martensiteand $\gamma 2$ phase, increase aging time led to increase amount of precipitate of $\gamma_{2}$. Figures 7-16 shows martensite phase at different magnifications [5-10].

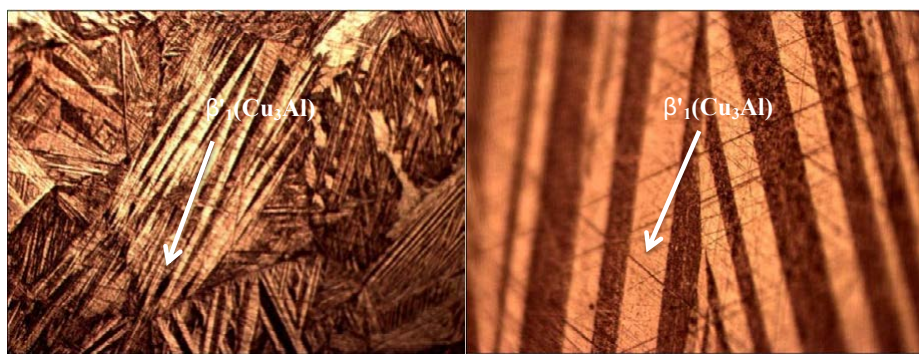

(a)

(b)

Figure 7: Plate of martensite phase at different magnifactions by optical microscope. (a) at 10x and (b) at 40x

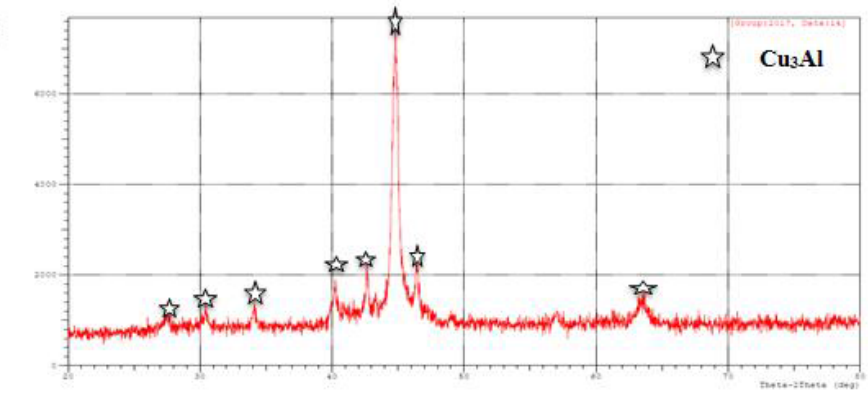

Figure 8: X-ray diffraction of Cu-Al-Be shape memory alloy.

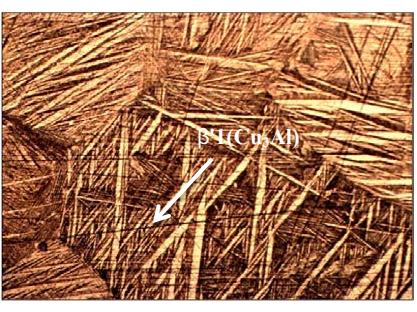

(a)

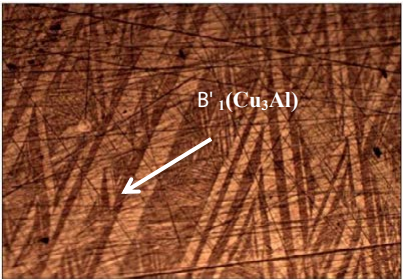

(c)

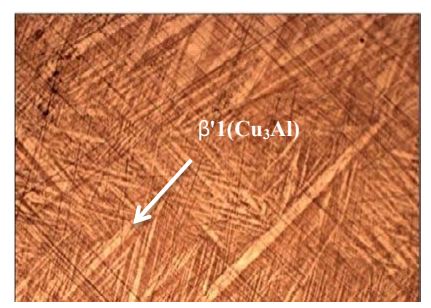

(b)

Figure 9: Effect of heat treatment on microstructure by optical microscope at magnification (10x). (a) $150^{\circ} \mathrm{C} 2 \mathrm{~h}$ salt ice water quenching (b) $150^{\circ} \mathrm{C} 4 \mathrm{~h}$ water quenching (c) $150^{\circ} \mathrm{C} 6 \mathrm{~h}$ salt ice water quenching. 
Citation: Al-haidary JT, Mastafa AM, Aziz Hamza A (2017) Effect of Heat Treatment of Cu-Al-Be Shape Memory Alloy on Microstructure, Shape Memory Effect and Hardness. J Material Sci Eng 6: 398. doi: 10.4172/2169-0022.1000398

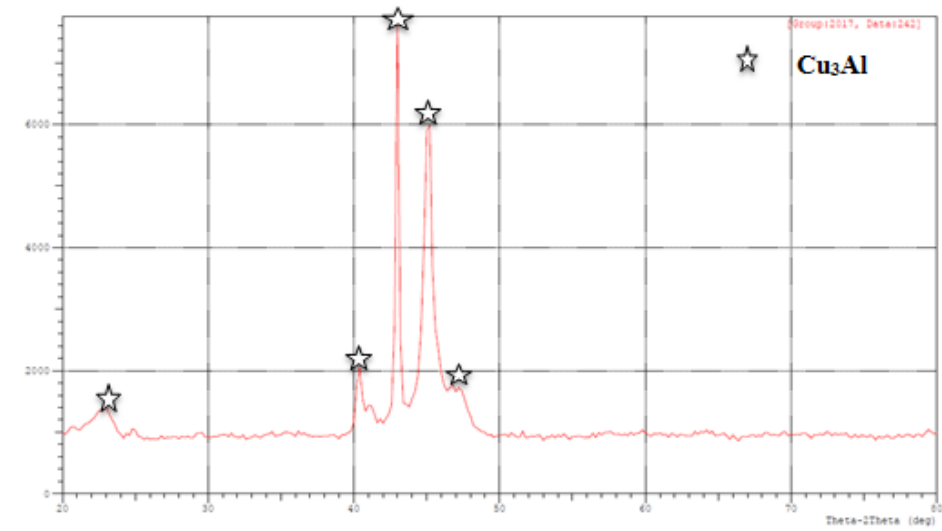

Figure 10: X-ray diffraction of Cu-Al-Be shape memory alloy that heat treatment at $150^{\circ} \mathrm{C}$ for $6 \mathrm{~h}$ and quenching in salt ice water.

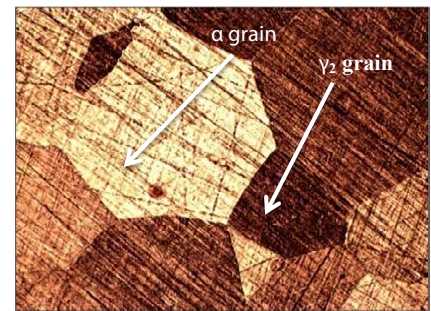

(a)

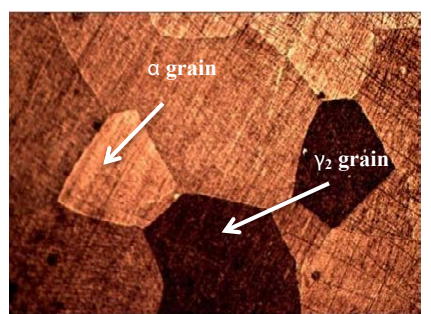

(b)

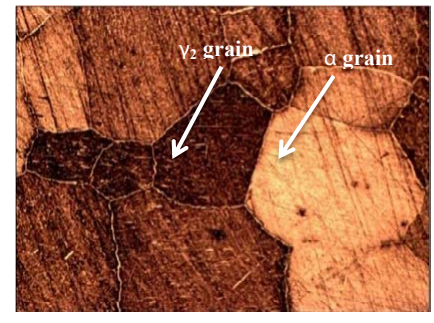

(c)

Figure 11: Effect of heat treatment on microstructure by optical microscope at magnifaction (10x). (a) $450^{\circ} \mathrm{C} 2 \mathrm{~h}$ water quenching (b) $450^{\circ} \mathrm{C} 4 \mathrm{~h}$ water quenching (c) $450^{\circ} \mathrm{C} 6 \mathrm{~h}$ water quenching.

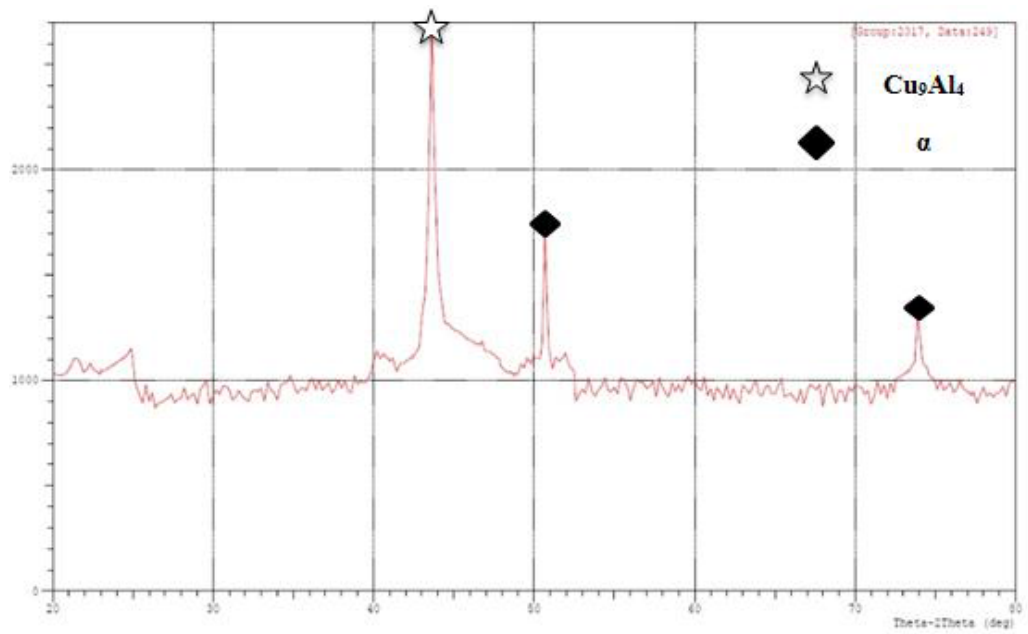

Figure 12: X-ray diffraction of Cu-Al-Be shape memory that heat treatment at $450^{\circ} \mathrm{C}$ for $6 \mathrm{~h}$ and quenching in water. 
Citation: Al-haidary JT, Mastafa AM, Aziz Hamza A (2017) Effect of Heat Treatment of Cu-Al-Be Shape Memory Alloy on Microstructure, Shape Memory Effect and Hardness. J Material Sci Eng 6: 398. doi: 10.4172/2169-0022.1000398

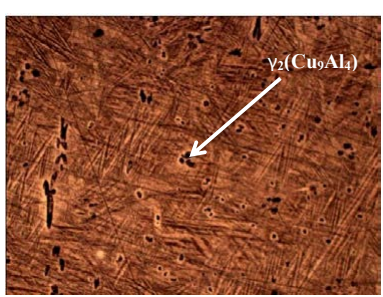

(a)

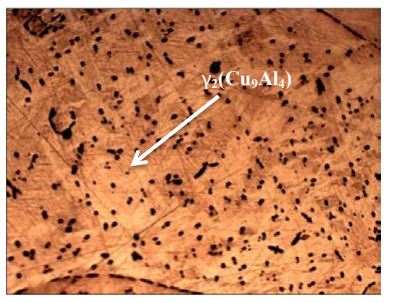

(c)

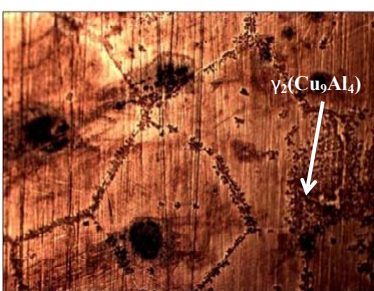

(b)

Figure 13: Effect of heat treatment on microstructure by optical microscope at magnifaction (10x). (a) $550^{\circ} \mathrm{C} 2 \mathrm{~h}$ salt ice water quenching (d) $550^{\circ} \mathrm{C} 4 \mathrm{~h}$ salt ice water quenching $(\mathrm{g}) 550^{\circ} \mathrm{C} 6 \mathrm{~h}$ salt ice water quenching.

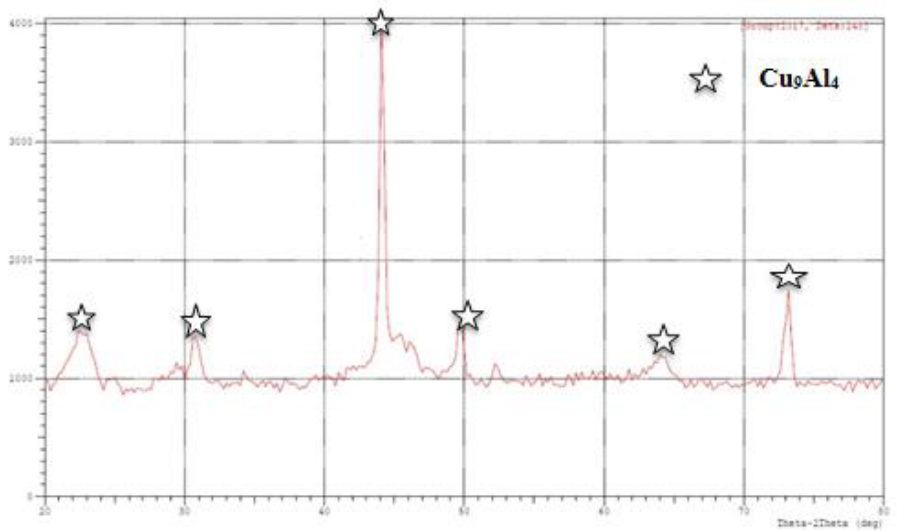

Figure 14: X-ray diffraction of Cu-Al-Be shape memory that heat treatment at $550^{\circ} \mathrm{C}$ for $6 \mathrm{~h}$ and quenching in salt ice water.

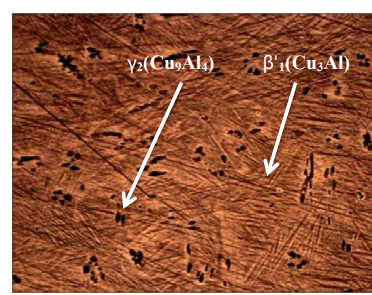

(a)

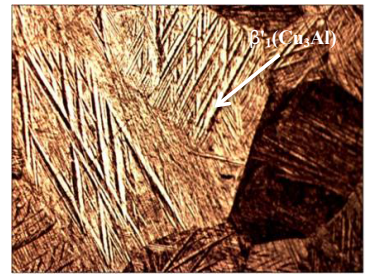

(c)

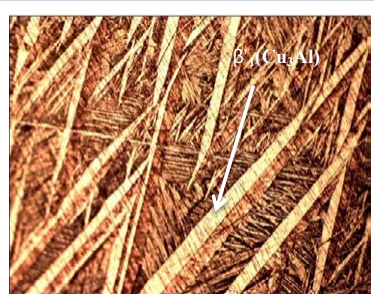

(b)

Figure 15: Effect of heat treatment on microstructure by optical microscope at magnification (10x). (a) $650^{\circ} \mathrm{C} 2 \mathrm{~h}$ salt ice water quenching (b) $650^{\circ} \mathrm{C} 4 \mathrm{~h}$ salt ice water quenching (c) $650^{\circ} \mathrm{C} 6 \mathrm{~h}$ salt ice water quenching. 


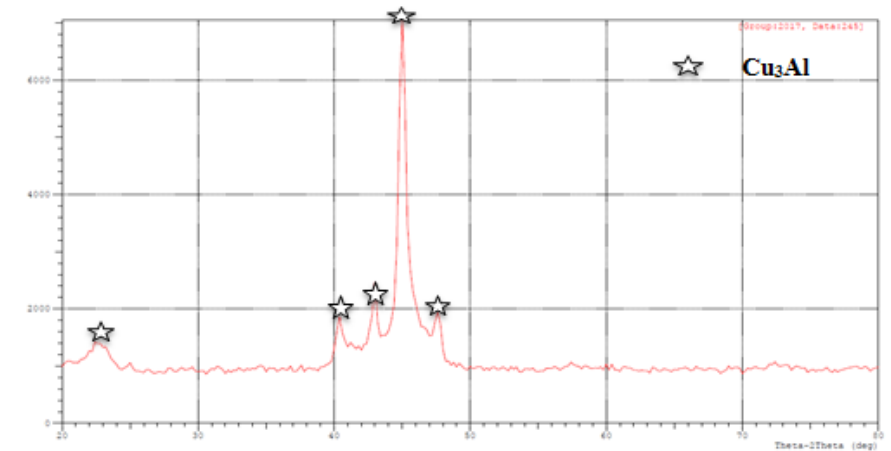

Figure 16: X-ray diffraction of $\mathrm{Cu}-\mathrm{Al}-\mathrm{Be}$ shape memory alloy that heat treatment at $650^{\circ} \mathrm{C}$ for $6 \mathrm{~h}$ and quenching in ice water.

\begin{tabular}{|c|c|c|c|c|c|}
\hline Heat treatment & $\mathrm{d}(\mathrm{mm})$ & $\mathrm{t}(\mathrm{mm})$ & $\theta e$ & $\theta m$ & SME\% \\
\hline Shape memory alloy & 18 & 1.2 & 145 & 155 & 86 \\
\hline $150^{\circ} \mathrm{C} 2 \mathrm{~h}$ ice water quenching & 18 & 1.2 & 151 & 170 & 94 \\
\hline $150^{\circ} \mathrm{C} 3 \mathrm{~h}$ ice water quenching & 18 & 1.2 & 154 & 174 & 96 \\
\hline $150^{\circ} \mathrm{C} 4 \mathrm{~h}$ ice water quenching & 18 & 1.2 & 154 & 175 & 97 \\
\hline $450^{\circ} \mathrm{C} 2 \mathrm{~h}$ ice water quenching & 18 & 1.2 & 130 & 140 & 77 \\
\hline $450^{\circ} \mathrm{C} 3 \mathrm{~h}$ ice water quenching & 18 & 1.2 & 110 & 130 & 72 \\
\hline $450^{\circ} \mathrm{C} 4 \mathrm{~h}$ ice water quenching & 18 & 1.2 & 100 & 110 & 61 \\
\hline $550^{\circ} \mathrm{C} 2 \mathrm{~h}$ ice water quenching & 18 & 1.2 & 140 & 150 & 83 \\
\hline $550^{\circ} \mathrm{C} 3 \mathrm{~h}$ ice water quenching & 18 & 1.2 & 120 & 135 & 75 \\
\hline $550^{\circ} \mathrm{C} 4 \mathrm{~h}$ ice water quenching & 18 & 1.2 & 110 & 120 & 66 \\
\hline $650^{\circ} \mathrm{C} 2 \mathrm{~h}$ ice water quenching & 18 & 1.2 & 150 & 165 & 91 \\
\hline $650^{\circ} \mathrm{C} 3 \mathrm{~h}$ ice water quenching & 18 & 1.2 & 155 & 170 & 94 \\
\hline $650^{\circ} \mathrm{C} 4 \mathrm{~h}$ ice water quenching & 18 & 1.2 & 165 & 175 & 97 \\
\hline
\end{tabular}

Table 2: Effect of heat treatment on shape memory effect.

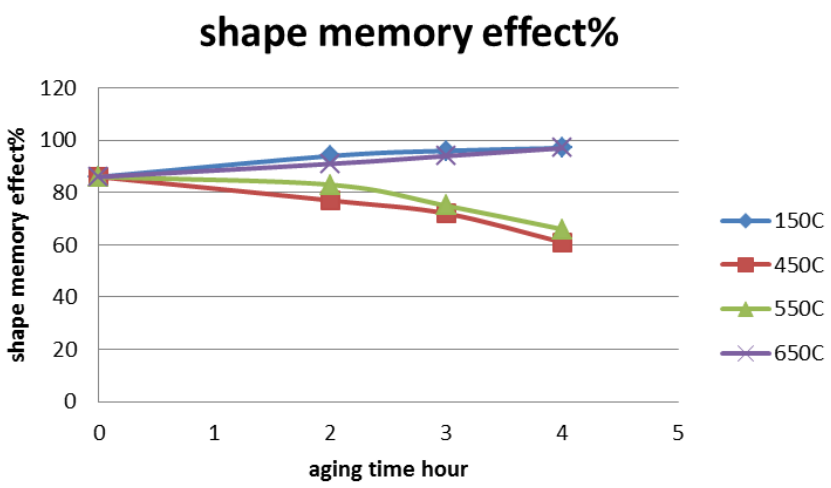

Figure 17: Effect of aging time and temperature on shape memory effect.

\section{Shape memory effect}

Effect on heat treatment on shape memory effect, shape memory alloy as received have thick plate of martensite phase and when aging at $150^{\circ} \mathrm{C}$ that can effect on martensite plate by produced small and fine plate of martensite plate, which increase in shape memory effect than thick plate aging at $450^{\circ} \mathrm{C}$ martensite phase transform into $\gamma_{2}$ and a phase, increase aging time led to increase transform martensite phase to $\gamma_{2}$ and $\alpha$ phase that decrease shape memory effect. Aging at $550^{\circ} \mathrm{C}$ also led to transform martensite phase into $\gamma_{2}$ phase, increase aging time led to increase transform martensite phase into $\gamma_{2}$ phase that decrease shape memory effect. when heat treatment at $650^{\circ} \mathrm{C}$ at $2 \mathrm{~h}$ produce $\gamma_{2}$ and very fine plate of martensite phase, this very fine plate martensite phase increase in shape memory effect and 3 and 4 hour form fine martensite phase only without $\gamma_{2}$ phase that cause increase shape memory effect $[11,12]$ (Table 2 and Figure 17).

\begin{tabular}{|l|c|}
\hline \multicolumn{1}{|c|}{ Heat treatment } & HV \\
\hline Shape memory alloy as received & 178.76 \\
\hline Heat treatment at $150^{\circ} \mathrm{C} 2 \mathrm{~h}$ ice water quenching & 165.23 \\
\hline Heat treatment at $150^{\circ} \mathrm{C} 4 \mathrm{~h}$ ice water quenching & 220.06 \\
\hline Heat treatment at $150^{\circ} \mathrm{C} 6 \mathrm{~h}$ ice water quenching & 226.43 \\
\hline Heat treatment at $450^{\circ} \mathrm{C} 2 \mathrm{~h}$ ice water quenching & 233.53 \\
\hline Heat treatment at $450^{\circ} \mathrm{C} 4 \mathrm{~h}$ ice water quenching & 253.16 \\
\hline Heat treatment at $450^{\circ} \mathrm{C} 6 \mathrm{~h}$ ice water quenching & 257.4 \\
\hline Heat treatment at $550^{\circ} \mathrm{C} 2 \mathrm{~h}$ ice water quenching & 238.5 \\
\hline Heat treatment at $550^{\circ} \mathrm{C} 4 \mathrm{~h}$ ice water quenching & 249.1 \\
\hline Heat treatment at $550^{\circ} \mathrm{C} 6 \mathrm{~h}$ ice water quenching & 313.16 \\
\hline Heat treatment at $650^{\circ} \mathrm{C} 2 \mathrm{~h}$ ice water quenching & 224.63 \\
\hline Heat treatment at $650^{\circ} \mathrm{C} 4 \mathrm{~h}$ ice water quenching & 217.76 \\
\hline Heat treatment at $650^{\circ} \mathrm{C} 6 \mathrm{~h}$ ice water quenching & 216 \\
\hline
\end{tabular}

Table 3: Effect of heat treatment on microhardness.

\section{Effect of heat treatment on microhardness}

Vickers microhrdness of heat treatment alloy show increases with increasing aging time. The formation of precipitation increased with increase aging time. The imperfection that percent in the alloy will move and fill the empty space at higher temperature which hardens the alloy. Increase aging time at $150^{\circ} \mathrm{C}$ which led to increase in microhardness because of martensite stabilization by precipitate, change vacancy concentration during aging and change lattice parameters of martensite phase. While increasing aging time at $450^{\circ} \mathrm{C}$ which led to more decomposed of martensite phase to $\alpha$ and $\gamma_{2}$ phase which led to increase in microhardness aging time at $550^{\circ} \mathrm{C}$ led to decomposed in to $\gamma_{2}$ phase and when increase aging time that increase $\gamma_{2}$ phase which increase microhardness. Aging $2 \mathrm{~h}$ at $650^{\circ} \mathrm{C}$ that form martensite and $\gamma_{2}$ phase which increase microhardness, while aging 
Citation: Al-haidary JT, Mastafa AM, Aziz Hamza A (2017) Effect of Heat Treatment of Cu-Al-Be Shape Memory Alloy on Microstructure, Shape Memory Effect and Hardness. J Material Sci Eng 6: 398. doi: 10.4172/2169-0022.1000398

Page 7 of 7

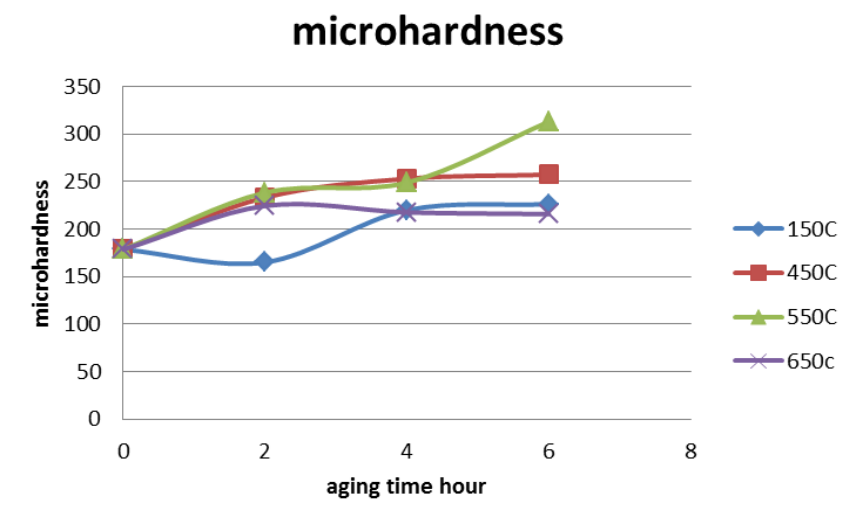

Figure 18: Effect of aging time and temperature on microvickers hardness

4 and $6 \mathrm{~h}$ which form only martensite phase that led to decrease in microhardness (Table 3 and Figure 18) [11,12].

\section{Conclusion}

- $\mathrm{Cu}-\mathrm{Al}-\mathrm{Be}$ shape memory alloy have high thermal stability.

- Heat treatment at $650^{\circ} \mathrm{C}$ and aging at $150^{\circ} \mathrm{C}$ increase shape memory effect.

- Aging at $450^{\circ} \mathrm{C}$ and $550^{\circ} \mathrm{C}$ decrease shape memory effect.

- Heat treatment at $650^{\circ} \mathrm{C}$ and aging at $150^{\circ} \mathrm{C}, 450^{\circ} \mathrm{C}$ and $550^{\circ} \mathrm{C}$ will increase in microhardness.

\section{References}

1. Chentouf SM, Bouabdallah M, Cheniti H, Eberhardt A, Patoor E, et al. (2010) Ageing study of Cu-Al-Be hypoeutectoid shape memory alloy. Materials Characterization 61: 1187-1193.
2. Mallik US, Sampath V (2008) Effect of composition and ageing on damping characteristics of Cu-Al-Mn shape memory alloys. Materials Science and Engineering: A 478: 48-55

3. Mallik US, Sampath V (2009) Influence of quaternary alloying additions on transformation temperatures and shape memory properties of Cu-Al-Mn shape memory alloy. Journal of Alloys and Compounds 469: 156-163.

4. Pahutova M, Šustek V, Čadek J (1995) Effect of thermal history on creep behaviour of a Cu-16Al solid solution alloy. Scripta metallurgica et materialia 33: 1013-1019.

5. Montecinos S, Simison S (2013) Corrosion behavior of Cu-Al-Be shape memory alloys with different compositions and microstructures. Corrosion Science 74: 387-395.

6. Belkahla S, Zuniga HF, Guenin G (1993) Elaboration and characterization of new low temperature shape memory CuAIBe alloys. Materials Science and Engineering: A 169: 119-124.

7. Montecinos S, Cuniberti A, Castro ML (2010) Kinetics of isothermal decomposition in polycrystalline $\beta$ CuAIBe alloys. Intermetallics 18: 36-41.

8. Cuniberti A, Montecinos S, Lovey FC (2009) Effect of ү2-phase precipitates on the martensitic transformation of a $\beta$-CuAIBe shape memory alloy. Intermetallics 17: $435-440$.

9. Ochoa-Lara MT, Flores-Zúñiga H, Rios-Jara D (2006) Study of y2 precipitation in Cu-Al-Be shape memory alloys. Journal of materials science 41: 5455-5461.

10. Montecinos S, Simison SN (2011) Study of the corrosion products formed on a multiphase CuAlBe alloy in a sodium chloride solution by micro-Raman and in situ AFM measurements. Applied Surface Science 257: 7732-7738.

11. Shivasiddaramiah AG, Mallik US, Devaraju S, Prashantha S (2016) Synthesis and evaluation of ageing effect on $\mathrm{Cu}-\mathrm{Al}-\mathrm{Be}-\mathrm{Mn}$ quaternary Shape Memory Alloys. Perspectives in Science 8: 113-116.

12. Prashantha S, Mallikarjun US, Shashidhara SM (2014) Effect of Ageing on Shape Memory Effect and Transformation Temperature on Cu-Al-Be Shape Memory Alloy. Procedia Materials Science 5: 567-574. 